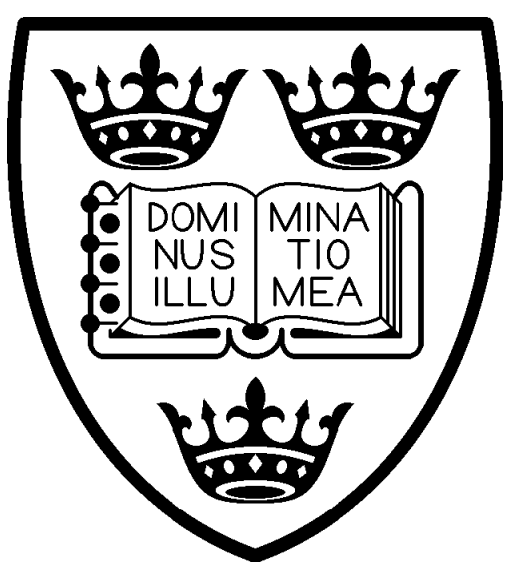

UNIVERSITY OF OXFORD

Discussion Papers in Economic and Social History

Number 142, March 2016

\title{
THE HAND-LOOM WEAVER AND THE POWER LOOM: A SCHUMPETERIAN PERSPECTIVE
}

Robert C. Allen 
The Hand-Loom Weaver and the Power Loom:

A Schumpeterian Perspective

by

Robert C. Allen

Global Distinguished Professor of Economic History

Faculty of Social Science

New York University Abu Dhabi

P.O. Box 129188

Abu Dhabi

United Arab Emirates

\author{
Senior Research Fellow \\ Oxford University \\ Nuffield College \\ New Road \\ Oxford OX1 1 NH \\ United Kingdom \\ bob.allen@nyu.edu
}

The empirics of this paper rest on John Lyon's Ph.D. dissertation The Lancashire Cotton Industry and the Introduction of this Powerloom, 1815-1850. This is an impressively well informed and thorough reconstruction of the technology and economics of the industry. This paper could not have been written without it. John Lyons sadly died in 2011. I dedicate the paper to him. 


\begin{abstract}
Robert C. Allen

The Hand Loom Weaver and the Power Loom: A Schumpeterian Perspective

Schumpeter's 'perennial gale of creative destruction' blew strongly through Britain during the Industrial Revolution, as the factory mode of production displaced the cottage mode in many industries. A famous example is the shift from hand loom weaving to the use of power looms in mills. As the use of power looms expanded, the price of cloth fell, and the 'golden age of the hand loom weaver' gave way to poverty and unemployment. This paper argues that the fates of the hand and machine processes were even more closely interwoven. With the expansion of factory spinning in the $1780 \mathrm{~s}$, the demand for hand loom weavers soared in order to process the newly available cheap yarn. The rise in demand raised the earnings of hand loom weavers, thereby, creating the 'golden age'. The high earnings also increased the profitability of developing the power loom by raising the value of the labour that it saved. This meant that less efficient-hence, cheaper to develop--power looms could be brought into commercial use than would have been the case had the golden age not occurred. The counterfactual possibilities are explored with a model of the costs of weaving by hand and by power. The cottage mode of production was an efficient system of producing cloth, but it self-destructed as its expansion after 1780 raised the demand for sector-specific skills, thus providing the incentive for inventors to develop a power technology to replace it. The power loom, in turn, devalued the old skills, so poverty accompanied progress.
\end{abstract}

JEL codes: N63, N34, O31

keywords: technological change, invention, technological unemployment, creative destruction 
Schumpter (1994, pp. 84, 87, 88) maintained that capitalism progressed through 'a perennial gale of creative destruction' in which new modes of production with higher productivity replaced older modes with lower productivity. In the course of advance, outmoded machinery was jumked, and workers with old fashioned skills lost their livelihoods as they too landed on the scrap heap of history. The genius of capitalism resides as much in the destruction of the old as in the creation of the new.

At the industry level, we can see the individual gusts that made up Schumpeter's gale. The Industrial Revolution consisted of one blast after another. The spinning of wool, flax, and later cotton was carried out by women working in cottages across England. Earnings were similar across all the sectors since women shifted between them, and all were eventually mechanized, so we do not draw sharp distinctions between the fibres. As the wool industry expanded in the seventeenth century due to an abundance of long haired sheep and growing demand from Britain's expanding mercantile empire, the employment of women rose. By the end of the seventeenth century, the labour market was tight, and their wage jumped up. The rise in their wage meant that Hargreaves' spinning jenny and Arkwright's water frame, which would not have been profitable to use in the conditions of the seventeenth century, suddenly became profitable. As a result, Hargreaves and Arkwright expended the resources to develop them. By the 1770 s, commercially viable designs were developed, and the factory production of textiles took off. The cottage mode of production was destroyed as women stopped spinning in their cottages, and their wheels were tossed in the barn. The 'contradiction' that led to the destruction of the cottage mode of production at its zenith was the shortage of skilled spinners (rather than the immiseration of the workforce that Marx supposed). Their high wages led inventors to develop a replacement technology that overturned the cottage mode and created the factory mode (Allen 2015).

This paper is about the next gust of creative destruction-the invention of power weaving and the demise of the hand loom weaver. The course of events was similar. The invention of machine spinning led to a huge supply of cheap yarn. The demand for weavers shot up. Figure 1 shows estimates of the number of weavers in Britain. At the peak around 1810-20, employment was close to a quarter million. As employment expanded in the late eighteenth century, the earnings of weavers were also bid up producing a golden age during the Napoleon Wars (Bythell 1969). It was the high wages earned by hand loom weavers in that period that led to the development of the power loom, for the high wages meant that less advanced versions of the power loom could be used commercially than would have been the case had wages remained at their earlier, lower levels. Less R\&D expenditure was necessary to make the transition from experimental designs to operational prototypes than would have been necessary earlier or would have been the case in other economies where wages were lower. This was the 'contradiction' through which the expansion of the cottage mode of production led to its own demise, as the factory replaced it. Once again the cottage mode of production was destroyed at its zenith not by the immiseration of the work force but by its prosperity. Immiseration quickly followed, however, for wages collapsed in the 1820 s and employment levels followed soon after. The weavers lost the high rent jobs they had enjoyed, and hand looms eventually became play things for the artsy-craftsy middle class.

These stories of technical change in the cotton industry bear on general explanations of the Industrial Revolution since they emphasize the importance of demand factors driving economic progress. Many widely accepted views emphasize factors affecting the supply of technology. Clark (2007) has offered a cultural explanation for the Industrial Revolution (in the aftermath of the black death, a 'genetic process' produced a British population that was better behaved and more responsive to economic incentives than people elsewhere), as has Mokyr (2002) (in the aftermath of the scientific revolution, communications networks sprang 
up in Britain in which natural philosophers offered businessmen tips on how to respond more scientifically to economic opportunities). On the other hand, North and Weingast (1989) and Acemoglu and Robinson (2012) have offered a political explanation (the Glorious Revolution replaced arbitrary royal government with the rule of law and security of property with the result that businessmen responded to economic incentives rather than being distracted by rent seeking). What these theories have in common is a focus on the responsiveness of economic actors to incentives in the market. The cultural or political change led businessmen and inventors to become more rational, savvy, confident, or focussed and consequently to respond better to their opportunities. The limitation of all of these theories is that they leave those opportunities unexamined. Did inventors in late eighteenth century England face the same opportunities as their ancestors or their counterparts in other countries? Was the Industrial Revolution the result of an unusual responsiveness to incentives or was it the result of unusual incentives? The Schumpeterian perspective explored here emphasizes how the evolution of markets created the incentives that inventors faced and can explain the timing of their efforts more precisely than other approaches.

\section{Locating the Golden Age}

The first step in understanding the competition between hand and power weaving is to analyse the income of hand weavers. There are two ways to ascertain it. The first is to collect contemporary estimates of weekly earnings. In reality, there was a range of income reflecting differences in skill and effort. To deal with that situation, Wood (1910, pp. 425-33, 593-6), Bowley 1902, pp. 106-8, 112-4) and Palgrave (1926, pp. 634-5), who collected this information, usually recorded the income of either a 'good' or an 'ordinary' worker. Feinstein (1998, p. 189) combined some early figures with Wood's index for the latter part of the period to form the series in Figure 1. In 1770, earnings were not particularly high, but they grew rapidly in the next twenty years as the factory production of cotton yarn exploded and along with it the demand for weavers. The years from 1793 to 1814 were the "halcyon days" in which "the hand-loom weaver was in the enviable position of a man who had something valuable to sell and could make very comfortable terms for himself." (Hammond and Hammond 1919, p. 18) After Waterloo, the hand loom weaver's fortunes reversed, and their circumstances became grim, indeed.

Weavers ordinarily worked in their cottages and were supplied with yarn by a manufacturer, who collected the finished cloth and paid them by the piece. As well as organizing production, the manufacturer inventoried raw materials and finished cloth. He also prepared the beam, that is the shaft around which was wound the thousands of lengths of yarn that comprised the warp of the cloth. These beams were then mounted on the looms and were crisscrossed with weft as each piece of cloth was woven. The price the manufacturer received for the cloth equalled the cost of the yarn plus his costs and income as well as the payment to the weaver, so we can calculate the weaver's income by subtracting yarn and manufacturers' costs from the sale price of the cloth. This is the second way to measure the earnings of handloom weavers. Its virtue is that it explicitly links together technical coefficients and prices, so counterfactual calculations are possible. In the event, it also corroborates the contemporary estimates.

There was a great variety of cloths, that differed in terms of the fineness of the yarn and the character of the weave. I concentrate on what has come to be called Neild printer's 
cloth $^{1}$ since it was an industry standard that was widely produced and has been well documented. The precise specification of the cloth is important. A piece of cloth was 29 yards long and 28 inches wide. It was woven with 36 count yarn with a weave of 84 threads per inch of weft and 77 threads per inch of warp. Each piece contained 2.215 pounds of warp and 2.415 pounds of weft (Lyons 1977, p. 195). These are key parameters for computing cost.

How much of this cloth could be woven in a week? The answer depends on how many hours the weaver worked and how much was produced each hour. There was a considerable range in productivity, so I concentrate on a 'good' male working full time. Following Voth's (2000, pp. 118-33) analysis of the working day, I assumed that weavers worked five days per week (they celebrated Sunday and Saint Monday) and 11 hours per day. One and a half of those work hours were, however, devoted to eating, so actual work hours were 9.5 per day or 47.5 per week. A work day of 9 hours is taken as the standard in the Indian Report of the Fact-Finding Committee (Handloom and Mills) (1942, pp. 57-9), which provides some corroboration. In addition, these studies show that only about $65 \%$ of the weaver's work time was actually spent moving the shuttle across the loom. The other $35 \%$ was taken up with set-up tasks and repairing broken threads (Latif 1997, p. 197).

How much cloth was produced depended on how many times per minute the shuttle moved across the loom when weaving was actually under way. Each traverse of the shuttle constituted a pick, and the pick rate of a good weaver was said to be 100 shots per minute in the Industrial Revolution. ${ }^{2}$ Confirmation of this figure comes from Egyptian and modern Indian sources that report similar values. (Latif 1997, p. 197, Clark 1908, p. 51). Allowing for $35 \%$ downtime, the good weaver achieved an 'effective pick rate' of 65 picks per minute averaged over the working day. Given that printer's cloth contained 84 threads per inch of weft, a weaver produced 61.26 yards per day. In a year a weaver produced 3062.5 yards or 105.6 pieces of 29 yards each.

While printer's cloth is the focus of this study, I also analyse a coarser cloth that was more typical of production in the early stages of the cotton industry. The paradigm is Cardwell's 'fine' calico, whose price was reported by Harley $(1998$, p. 79) for the period 1779-98. It was made from 20 count warp and 18 count weft ${ }^{3}$. We do not have a description of the cloth reporting the number of warp and weft threads per inch, but these can be worked out from the norms for Indian hand woven cloth in the 1950s. ${ }^{4}$ Again assuming that the weaver makes 100 picks per minute during his 'up time,' he wove 3.66 pieces per week of 28

\footnotetext{
${ }^{1} \mathrm{~A}$ price series for this specification of cloth was originally published by Neild (1861).
}

${ }^{2}$ This rate is achieved on cloth one yard wide. On broadcloth, the rate dropped to 80 . White (1846, pp. 32-3).

${ }^{3}$ Harley (1998, P. 79) states that the cloth was made with 18 count yarn. Harley reports a price for 18 count weft but 20 count warp, and so I base costs on that description.

${ }^{4}$ Amalsad (1961) not only explains the methodology but provides a worked example on pp. 20-22 that can be readily adapted to Cardwell's fine calico. Amalsad's example is for a piece of Grey Long Cloth 36 inches wide and 40 yards long with a warp of 20 count and a weft of 18 and a $54 \times 50$ weave. 
yards each, and each piece required $3.598 \mathrm{lbs}$ of warp and $3.68 \mathrm{lbs}$ of weft.

With these analyses of the productivity of a handloom weaver, we can calculate the income per day of the weaver from the prices of cloth, yarn, and manufacturers' costs according to the formula:

income $/ \mathrm{wk}=($ price - yarn cost - manufacturers' costs and income $) *$ pieces per week

Figure 2 shows the incomes of 'good' male weavers from 1770 through $1839^{5}$. The figure also shows the daily income of a building labourer. In 1768 when Arthur Young visited Manchester, a weaver and a building labourer had similar earings. Around 1780, at the start of the great cotton boom, hand loom weavers had high earnings making coarse cloth, but by the late 1780 s and for the early 1790 s, their earnings (while variable) were like those of labourers.

From the late 1790s, the earnings of handloom weavers surged, and they earned more than labourers for the next 20 years (although their earnings dropped briefly after the resumption of war in 1803). The premium over the labourer was the 'rent' that the handloom weaver earned as a return to his now scarce skill. This was the famous 'golden age of the handloom weaver.' It was important in the social history of the period, and it was important for its technological history, as we shall see.

\section{The invention of the power loom}

The Rev. Edmund Cartwright ${ }^{6}$ is credited with inventing the power loom, although he never succeeded in making a commercially viable model. In 1784 while in Matlock on

${ }^{5}$ The data to calculate income are taken from the following sources:

price-price of a piece of printer's cloth for 1812-60 as reported by Neild (1861), standardized for size by Lyons (1977, p. 195), and extended back to 1781 by Harley (1998, pp. 80-2). For Carldwell's fine calico, I use Harley (1998, p. 79).

yarn prices-for Neild cloth, see Appendix. For Caldwell's fine calico, 18 count weft was taken from Harley (1998, p. 74) and 20 count warp from Harley (1998, p. 75) with some interpolations based on the price of 18 count weft.

manufacturer's current costs-from Lyons (1977, pp. 244-7).

manufacturer's fixed capital costs-Lyons (1977, pp. 250-1)

manufacturer's working capital costs-Lyons (1977, pp. 251-2). The value of inventory was a function of its price, and it was necessary to solve this out in computing the supply price of handloom cloth when the weaver's wage was changed to the building labourer's wage. manufacturer's income-set to $£ 130$ per year in 1815 on a production rate of 22500 pieces per year (Lyons 1977, p. 211n20). This output equalled the capacity of the warping machine and corresponded roughly to that of Lyon's model power mill at the same date. Entrepreneurial income was kept constant in later years in view of the roughly constant nominal wage level in manufacturing. Incomes before 1810 were reduced in accord with the wage of a building labourer in Lancashire.

${ }^{6}$ This section is based on Cartwright's biography by Hunt (2004). 
holiday, he dined with 'some gentlemen from Manchester' and proposed that weaving be mechanized as spinning had been. Cartwright's suggestion was inspired by French automatons-the mechanized figures that moved in lifelike ways. ${ }^{7}$ If a mechanical woman could play a dulcimer, couldn't she also weave calico? Despite knowing nothing of machinery, Cartwright made a mechanical loom after his holiday. The device was cumbersome and required two men to operate; nonetheless, he received a patent for it.

Cartwright's loom was not commercially viable and illustrates the fundamental character of eighteenth century invention. Invention was not primarily about novel ideas; instead, it consisted of the practical engineering that converted often banal ideas into reliable machines that were cost effective in production. As Thomas Edison quipped, 'invention is one per cent inspiration and ninety-nine percent perspiration." Since invention meant R\&D, it required the expenditure of money and resources, and so it responded to economic incentives.

Cartwright expended a fortune trying to perfect his loom. He employed skilled mechanics to do the work and received patents on improved designs in 1786, 1787, and 1790 . In the late $1780 \mathrm{~s}$, he built a 20 loom mill, powered first by a bull and then by a steam engine. In 1790, a 400 loom mill was built by leasees, but it was burnt down. That was the end of Cartwright's experiments. He had invested about $£ 30,000$ in the power loom.

Other inventors also worked on the problem in the 1790s. (Cartwright complained about infringements of his patents and was awarded $£ 10,000$ in compensation by Parliament in 1809.) The key breakthrough was made by William Horrocks in Stockport. He started working with power looms in 1795 and had about 50 in operation in 1800 . In 1803 he received a patent for his major invention which was the use of a crank to drive the parts of the loom rather than cams as in the earlier designs of Miller and Austin. Horrocks' loom was the first to make the transition from R\&D to commercial use (Timmins 1996, p. 46, Lyons 1977 , p. 69, 115, 116 n. 6).

\section{Productivity growth in power weaving}

Power weaving was much more capital-intensive than hand weaving. It required a multi-storey building, a steam plant for power, and many looms since operations had to be on a large scale. The factory also housed dressing, winding, warping, and looming machines. In the first half of the nineteenth century, there were improvements in the design of the steam plant and in some ancillary machinery, but productivity growth in power weaving was primarily driven by two major improvements. One was the invention of the dressing machine by Thomas Johnson of Stockport and also patented in 1803 (Marsden 1895, p. 70). This allowed the warp to be sized with flour before being mounted on the loom and thereby saved the weaver a protracted period of winding and dressing rather than weaving. The upshot was that a weaver (plus an assistant) could operate two looms instead of only one, and that pushed up labour productivity.

The other was a series of improvements that increased the speed (pick rate) of the power loom. This also raised output per worker since each loom produced more fabric in a given time period. Horrocks' 1803 design had an effective pick rate of 35 per minute

${ }^{7} \mathrm{He}$ adduced as an example the mechanical chess player then on display in London (Marsden 1895, p. 60). This has since been shown to have been a fraud. See the entry for the Turk in Wikipedia. 
(probably with an operating pick rate of 52 and an 'uptime' of 65\%). This was obviously less than the effective rate of a good handloom weaver ( 65 picks per minute). How could it compete? It had three advantages. The first was that Horrocks' loom was installed in a factory where it could be worked for 12-14 hours per day rather than the shorter day worked by a handloom weaver in his cottage. This may have been an example of Marglin's (1974) thesis that factories gained their advantage over hand workers by allowing the owner of the factory to dictate the pace and duration of the work day. The second was that the power loom was operated by women who were paid less than handloom weavers earned-another aspect of Marglin's theory. The third factor making the power loom commercially viable was the invention of the dressing machine, which increased labour productivity on power looms.

Horrocks' loom was the first commercially successful design, but it barely covered its costs and it was slow. A famous series of improvements were made in loom design in the next half century, and they increased the pick rate and extended the loom's capacities to finer and finer weaves. In the first two decades of the nineteenth century, a small number of firms installed power looms and the effective pick rate achievable with Horrocks' design was boosted to about 65 . The capacity of the power loom was extended from coarse calicos to medium grade fabrics like printer's cloth. (Lyons 1977, pp. 116-6, 181) The next major advance was due to a set of improvements patented by Richard Roberts in 1822 . They increased the effective pick rate to about 76. In 1828 William Dickson invented the over pick loom, which became the normal British design. By 1836 looms had achieved effective speeds of about 100 picks per minute. In 1842 the uptime and the speed were both increased by improvements designed by William Kenworthy and James Bullogh. Their loom had an effective speed of about 130 picks per minute. Further improvements raised the effective pick rate to 200 by 1860 (Lyons 1977, p. 181).

Economics of the Power Loom and its Invention

The power loom was an impressive achievement that required ingenuity and persistence to develop. The fundamental question is: Why was the power loom invented in England at the beginning of the nineteenth century? The inventors (developers) had to set the costs of developing the power loom against the income from operating it. The costs depended on how much development work they had to do, that is, how good the machine had to be in order for the value of the cloth to cover the costs. For Horrocks, an effective pick rate of 35 was good enough. The development costs would have been far higher if a loom had had to have an effective pick rate of 100 to turn a profit. Higher development costs would have reduced the likelihood of invention. I will argue that the power loom was developed to the point of commercial use in England around 1800 because the high wages earned by weavers lowered the break even speed of the machine to 35 picks per minute. If weavers had not earned high rents, it would have been necessary to develop a faster machine, and that would have been a more expensive R\&D project. Likewise, in other parts of Europe where wages were much lower, much faster machines would have had to be developed before they could be commercially used, and that would have retarded invention.

Figures 3-6 summarize the argument. In 1780 a hand loom was the only way to weave cotton cloth, and it is represent as a single point in Figure 3. It was the least cost technique whatever the relative factor prices, as indicated by two iso-cost lines representing a high and a low wage relative to the price of capital services. The power loom represent a substantial increase in the capital-labour ratio (Figure 4). It cut costs in the high wage 
situation but not in the low wage situation. One interpretation of Figure 2 is that the high wage situation represents the high wages of weavers in 1793-1814, while the low wage isocost line represents the earlier situation before weavers earned high rents.

Figure 5 adds a line running from the power loom isoquant towards the origin. It represents the trajectory of improvements made by inventors and businessmen after the power loom came into commercial use. The point where this line intersects the isocost line for the low wage situation is a tipping point, for the power loom has then been improved enough for it to be the least cost technique in the low wage situation. If we interpret the low wage situation to be France, the tipping point represents the loom vintage which diffused across the channel, as France skipped the intermediate steps and jumped to the most advanced technology.

Figure 6 adds a dotted line between the power loom isoquant and point $\mathrm{C}$. The latter represents Cartwright's first design for a power loom. It did not pay at any factor prices. The dotted line between $\mathrm{C}$ and $\mathrm{P}$ represents the improvements effected by Cartwright, Horrocks and others that turned the power loom from an R\&D project into a machine that was commercially viable. Had this $R \& D$ project been undertaken in the low wage situation, the $R \& D$ trajectory would have been longer since the loom would have had to be perfected to the design at the tipping point. (This additional R\&D is represented in Figure 6 by the double line between the power loom isoquant and the tipping point.) The R\&D project would have been more substantial and more costly, so the likelihood of its being carried out would have been less.

I will develop this argument numerically by computing the rate of return to installing power looms of various technical specifications. I focus on the period 1800-14, which was the golden age of the handloom weaver as well as the period when the key investment decisions was taken by Horrocks and others. Profitability is evaluated with average prices, wages, and earnings over this period, and profitability is computed over a ten year horizon, which is appropriate since most of the capital expenditure consisted of machinery.

Costs and revenues for these calculations are derived mainly from Lyons's (1977) remarkable Ph.D. dissertation. Lyons developed the costs for a model cotton mill with a 10 horsepower steam engine, which was the minimum efficient size. This implied a mill of 100 looms since each loom required 1/10 horsepower. Lyons worked out the design and costs of the mill for each year from 1815 to 1852 . He specified the required warping, winding, and looming machines as well as dressing machines once they were invented. Using firm accounts and industry manuals, Lyons worked out the numbers and costs of the machines, and the attendant workforce. These numbers changed as the technology advanced. Lyons also worked out associated costs like the coal burnt in the steam plant, flour used for sizing, lubricants, various overheads, inventories and so forth.

Another important change between 1815 and 1852, of course, was the increase in the speed of the looms. That meant that output and revenues increased over time. Yarn costs also increased proportionately. These were the biggest share of variable costs.

While Lyon's aim was to compute the profitability of building a weaving mill using the prices and best practice technology each year from from 1815 to 1852 , my objective is to use the information to compute the profitability of using different technical designs with the prices prevailing in 1800-14. The rate of return is computed by solving the following formula for $r$ :

$$
\mathrm{K}=\sum(\mathrm{pq}-\operatorname{costs}) /(1+\mathrm{r})^{\mathrm{t}} \text { where the summation is from } \mathrm{t}=1,2, \ldots 10
$$


Here $\mathrm{K}$ is the cost of building the mill and depended in a small way on whether dressing machines were installed. $p$ is the price of a piece of cloth. It also equals the price of hand woven cloth in equation 1. Equation 2 evaluates the power loom both as an investment in its own right and as an improvement vis-à-vis the hand loom. $\mathrm{q}$ is the annual production of the mill. The mill has 100 looms, so q increases in step with the pick rate. Costs are all of the annual costs of operating the power loom mill. They include the cost of yarn, coal, flour for sizing, production labour, overhead labour, overhead expenses, and interest on working capital. Yarn cost was proportional to output as was some of the labour cost. However, most of the labour cost, in particular the wages of weavers, was fixed since each weaver operated one or two looms (depending on whether or not there were dressing machines) irrespective of how much the loom produced. Sources are listed in the Appendix.

The first set of calculations of the profitability of building a power loom factory assume that the price of printer's cloth equalled its historical price averaged over the period. Implicitly, this assumes that handloom weavers received their historical earnings. The profit rate is computed for different effective pick rates of the loom that run the gamut from Horrocks' first loom (35) to the greatly improved looms of the mid-nineteenth century. The profit rate also depended on the use of the dressing machine.

The dressing machine was crucial in making the power loom profitable. Figure 7 shows why. Without a dressing machine, Horrocks' 35 pick per second loom would not have covered its variable costs. At 39 picks per second, it would have realized a return of $-32 \%$, so it would not been installed commercially. R\&D would have been extended (i.e. Horrocks or someone else would have had to spend further sums perfecting the machine without receiving any immediate return from its use). Commercial operation would have required the machine to have been improved to the standard of 1815 before it would have covered its costs.

When Horrocks' loom was used in combination with a dressing machine, however, it became commercially viable in a much more primitive form. Capitalists expected a return of $10-15 \%$ on fixed investment. ${ }^{8}$ This is, of course, a hard number to pin down exactly, so it is fortunate that values in this range give very similar results. The profitability model implies that Horrocks' loom, used in conjunction with a dressing machine, achieved a $15 \%$ rate of return with a pick rate of 38 (or 36 with a $10 \%$ return). In actual fact, Horrocks' loom became commercially viable with a pick rate of 35 . The fact that the model comes so close to predicting the pick rate when Horrocks' design transitioned from R\&D to commercial operation is evidence in favour of the model.

More primitive versions would not have paid. The profit rate of Horrocks' loom used in conjunction with the dressing machine would have been $-11 \%$ had it a pick rate of 30 , and it would not have covered its variable costs had the pick rate been only 25 . The improvements Horrocks effected in the power loom between 1795 and 1803 raised its efficiency enough to transit into commercial profitability when it was combined with Johnson's dressing machine.

These results are contingent on the exceptional features of the years 1800-14, namely, the high wages earned by handloom weavers and the high prices received for cloth. These

${ }^{8}$ Harley (2010) found that the return on to capital in the cotton textile during the Industrial Revolution was about 13\%, and Hudson (1986, pp. 235-41, 272, 277) calculated the profit rate on business capital to have been about $14 \%$ in the wool industry in the $1850 \mathrm{~s}$. 
were two sides of the same coin since the wage of the handloom weaver equalled the price of the cloth less the yarn, capital, and labour used in its production. The high prices and wages were themselves the result of the boom in the cotton industry set off by the invention of spinning machinery. They not only led to great prosperity and expansion of the cottage sector but also precipitated its demise by increasing the return to mechanization. We can see this by recomputing the return to installing power looms under a counterfactual scenario. The counterfactual is that spinning machinery did not create a boom in which handloom weavers received exceptional earnings. Around 1770 (before the boom), they only earned as much as building labourers. We can ask what the return to power weaving would have been had they continued to earn the wage of a building labourer, had they, in other words, earned no rents from 1793 to 1817 , or, to put it differently, had the golden age of the handloom weaver never taken place.

To perform the profitability calculations, we need to know what the price of printer's cloth would have been had handloom weavers earned the building labourer's wage. The price can be computed from equation 1 by reversing the earlier calculation and solving for the price by substituting the labourer's wage. This change would have cut the price of cloth from 279 pence per piece to 249 . The profit of using a power loom would have been cut as the new profit lines in Figure 7 indicate. Under this assumption, a power loom without a dressing machine would not have been commercially viable with an effective pick rate below about 80 . This level of efficiency was not reached until 1825 with Robert's loom. The situation would have been easier with the dressing machine since the break even pick rate would have been about 64. This rate was not achieved until 1822. A large amount of learning by doing occurred between the years that Horrocks' machine came into commercial use and the manufacture of these improved designs. In the absence of the 'golden age of the handloom weaver' the invention of the power loom would have been more expensive as the design that would have crossed the threshold to commercial viability would have had to have reached a higher standard of performance. Who would have financed all of this extra R\&D in the absence of the learning by doing? The conclusion must be that the invention of the power loom might never have happened in the absence of the golden age of the handloom weaver.

History performed a natural experiment that confirms this claim. There was a substantial linen industry in Ulster in the nineteenth century. Spinning flax by machine was a difficult challenge that was not met until 1825. However, the power looms that wove cotton cloth could weave linen with only minor modification. ${ }^{9}$ Yet the power loom was not used to weave linen in the 1840 s-by which time it had driven cotton handloom weavers out of business in Britain. Irish linen was still woven by hand. Ulster was so integrated with Britain in so many ways that one cannot explain the persistence of hand weaving in terms of political institutions, culture, lack of information, stature of the population, unavailability of equipment, etc. The big difference between Ulster and Britain was the lower wage level in Ireland. It was not profitable to mechanize spinning when labour was so cheap. The death and immigration triggered by the Famine in the 1840s changed the situation dramatically. The decline in the labour supply led to a rise in wages in the 1850s. Power weaving took off.

${ }^{9}$ Linen yarn is less elastic than cotton, and a small vibrating roller was added to the loom to reduce strain on the yarn. (Charley 1862, p. 90-1) The linen looms were also built more robustly than the cotton looms. 
So long as a man's labour could be had at the hand-loom in Ireland for a shilling a-day, it was felt no power-loom could work much, if at all cheaper; but when wages; some few years back, began to advance, and the population to decrease instead of increase, it was admitted that the power-loom was at length required. At present, one of the striking features in the linen trade is, the gradual introduction of power-looms for weaving the coarser qualities of cloth. (Charley 1862, p. 88).

The natural experiment of the Famine shows the sensitivity of adoption to the wage level. Even without the Famine, Ulster manufacturers would have eventually adopted the power loom, just as Indian entrepreneurs have done. But the loom would have had to have been improved to a standard not reached until much later. If we imagine inventors like Horrocks contemplating the improvement of the power loom under pre-Famine Irish conditions, it would have seemed to them a pointless prospect since a late nineteenth century vintage loom would have been beyond their grasp at any conceivable cost.

\section{$\underline{\text { Conclusion }}$}

The Industrial Revolution was one blast of Schumpeter's gale after another. Together they created an intertwined pattern of progress and poverty. Hobsbawm remarked that "Whoever says Industrial Revolution says cotton," and we can trace the gale through the textile industry.

The story begins around 1500 in the wool industry. Britain had an abundance of high quality wool, and the industry expanded four fold in the next 250 years. This required an increase in the number of spinners that greatly exceeded the growth in population. The work was done by women in their cottages, and by 1770 , the industry employed most of the women in the country. As employment expanded, so did spinners' earnings. The irony is that when the cottage mode of production was at its zenith, it self-destructed. The high wages earned by women in the eighteenth century meant that even inefficient machines like the first proto-types of Hargreave's jenny and Arkwright's water frame covered their costs. That would not have been the case in the seventeenth century when wages were lower, nor was it the case in the eighteenth in most other countries of the world. The fact that inefficient machines could be operated commercially meant that the R\&D problem was a relatively simple one, and that is why a Hargreaves and an Arkwright tackled it when and where they did.

Once these machines came into use, the factory mode of production took off. The price of yarn fell so steeply that women stopped spinning in their homes. The factory mode of production destroyed the cottage mode and created large scale technological unemployment for the first time. Men had to support their families without the earnings of their wives-the male breadwinner family was born. The earnings of agricultural labourers were inadequate to keep their families at a respectable level with a diet of white bread, beef, and beer. Instead, they ate potatoes and porridge. The political discourse referred to the poverty of the farm labourer and the burden he placed on the poor law. Certainly the agricultural labourer's earnings were inadequate, but the underlying cause was not the high birth rate that the Malthusians gestured to; rather, it was technological change in the textile industry that put many wives and mothers out of work. In the 1820s, William Cobbett (1967, p. 131) observed that "A part, and perhaps a considerable part, of the decay and misery of 
this place [Whitington, Glos.] is owing to the use of machinery...in the manufacture of blankets, of which fabric the town of Witney...was the centre, and from which town the wool used to be sent round to, and the yarn, or warp, come back from, all these Cotswold villages,...This work is all now gone, and so the women and girls are a 'surplus popalashon, mon"'.

The factory production of cotton yarn gave the cottage mode of production a new lease on life, but this time for men. The great growth in the supply of cheap yarn led to a rapid growth in demand for weavers. As their numbers expanded, so too did their wages. By the early nineteenth century, one in ten British men were weaving cotton, and in this golden age they earned double or triple what a labourer earned.

Then, as with the spinning sector, the high wages earned by hand loom weavers led inventors to develop the power loom to economize on their labour. The rents they earned meant that less efficient machines could cover their costs than would have been the case in other times and places. As a result, the profitability of invention was at its height, and the power loom came into commercial use.

While the invention of the power loom (like the spinning machines) was the result of high wages, the new technology led to poverty as the fall in the price of cloth drove the earnings of hand loom weavers down to bare bones subsistence. The 'standard of living issue' in the Industrial Revolution was the result of the destruction of hand loom weaving and other hand trades. Figure 10 makes the point. It shows the history of the real wages of building labourers, farm labourers, and hand loom weavers in Lancashire. At the outset, around 1770, their weekly earnings were similar. In the next 90 years, the earnings of hand loom weavers lept up and then collapsed. The real earnings of farm labourers changed little, while the earnings of building labourers steadily increased. By the middle of the nineteenth century, the building labourers earned three to four times as much as the hand weavers. The 'standard of living' issue was the result of this great growth in wage inequality. 
Figure 1

Weekly earnings (pence) of a hand loom weaver and a building labourer

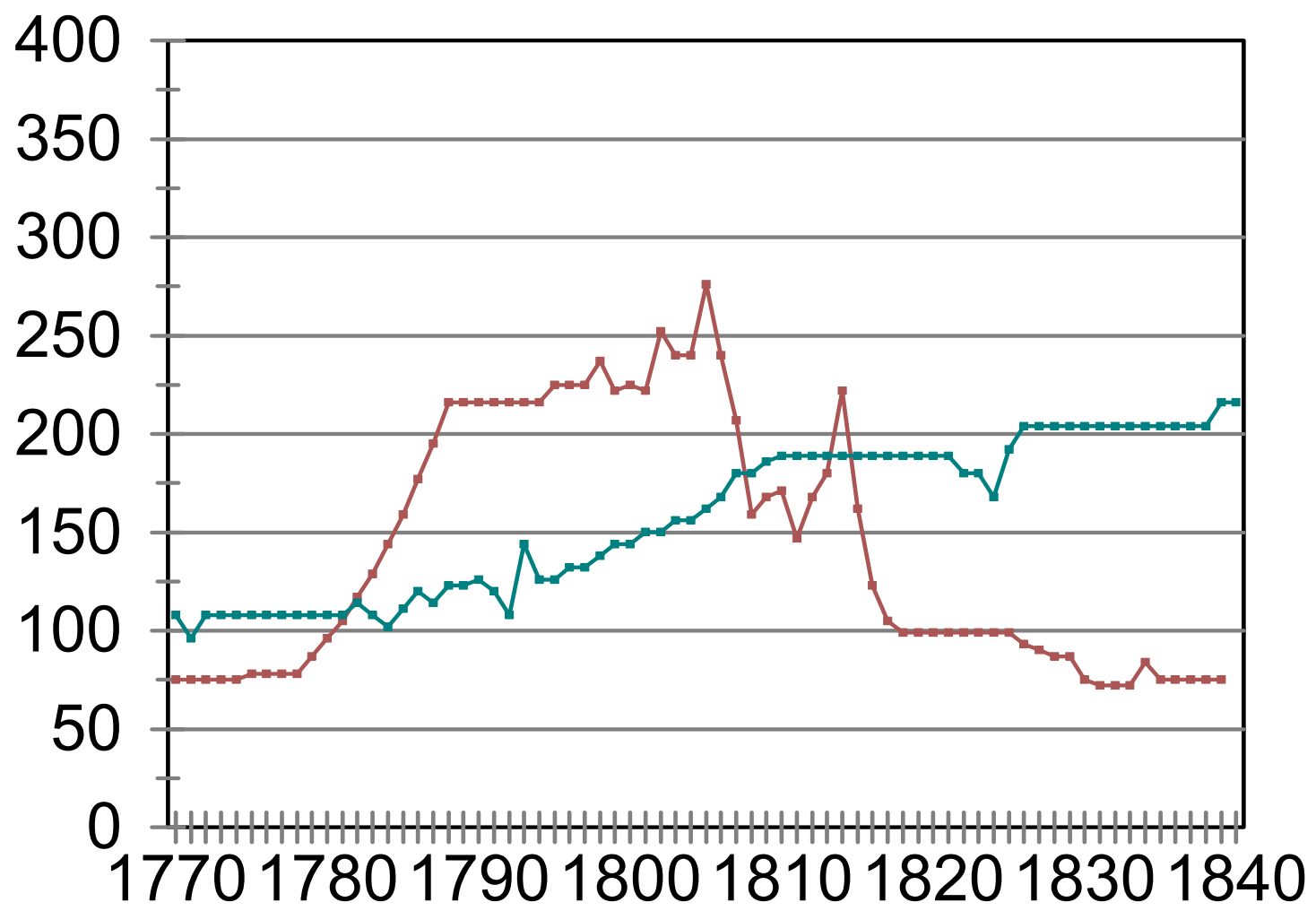

$\rightarrow$ - weaver (from Feinstein)

- building labourer

sources:

hand loom weaver-Feinstein's index based on Bowley, Palgrave, and Wood as described in Feinstein, (1998, p. 189).

building labourer-1700-94: Gilboy, Wages, pp.280-2. 1810-25: Tables of the revenue, p. 165. 1839-1900 Bowley (1900, pp. 310-11). 
Figure 2

Computed weekly earnings (pence) of hand loom weavers from different cloths

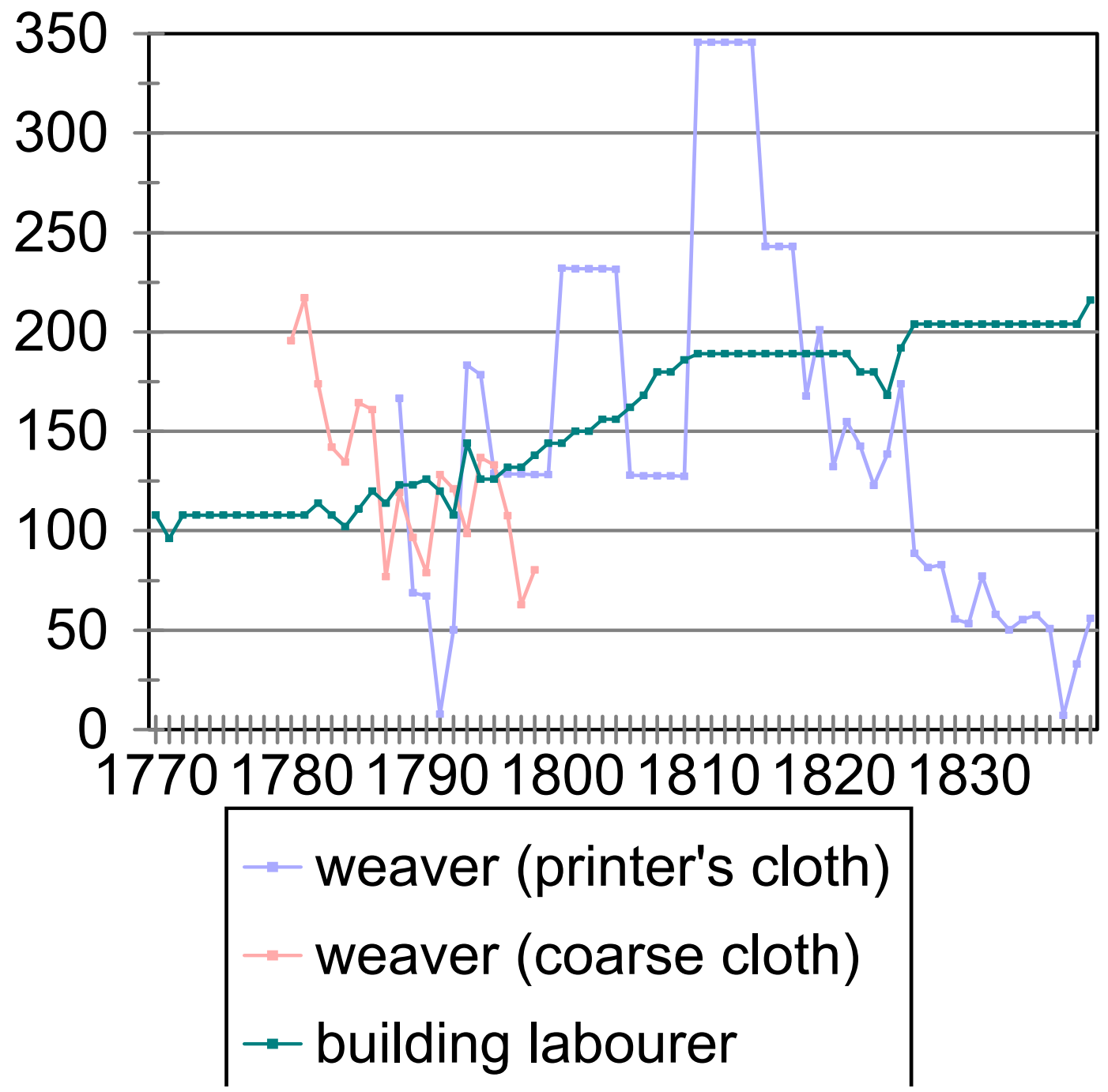

See text 
Figure 3

Isoquant of hand loom

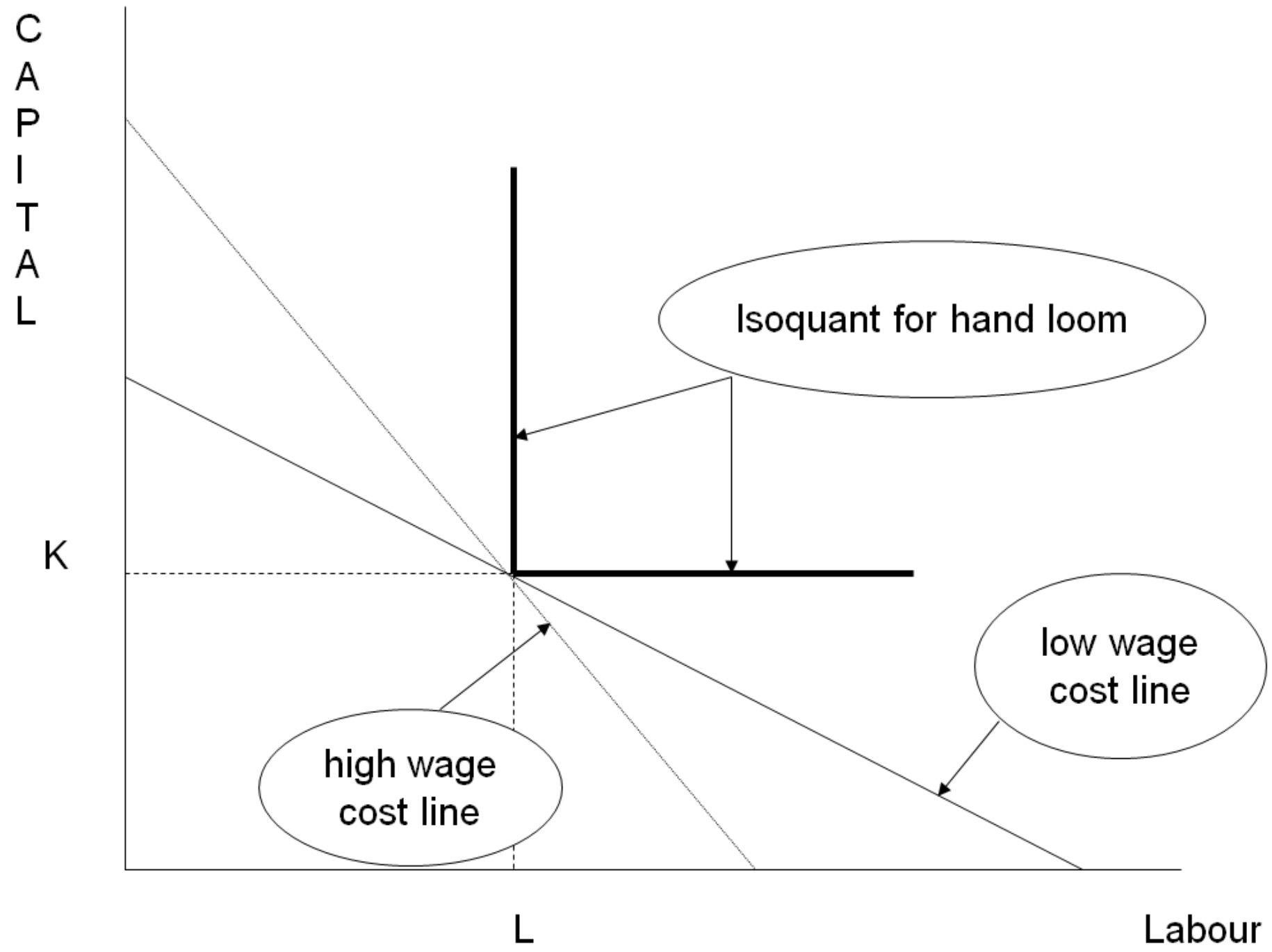


Figure 4

hand loom and power loom isoquants

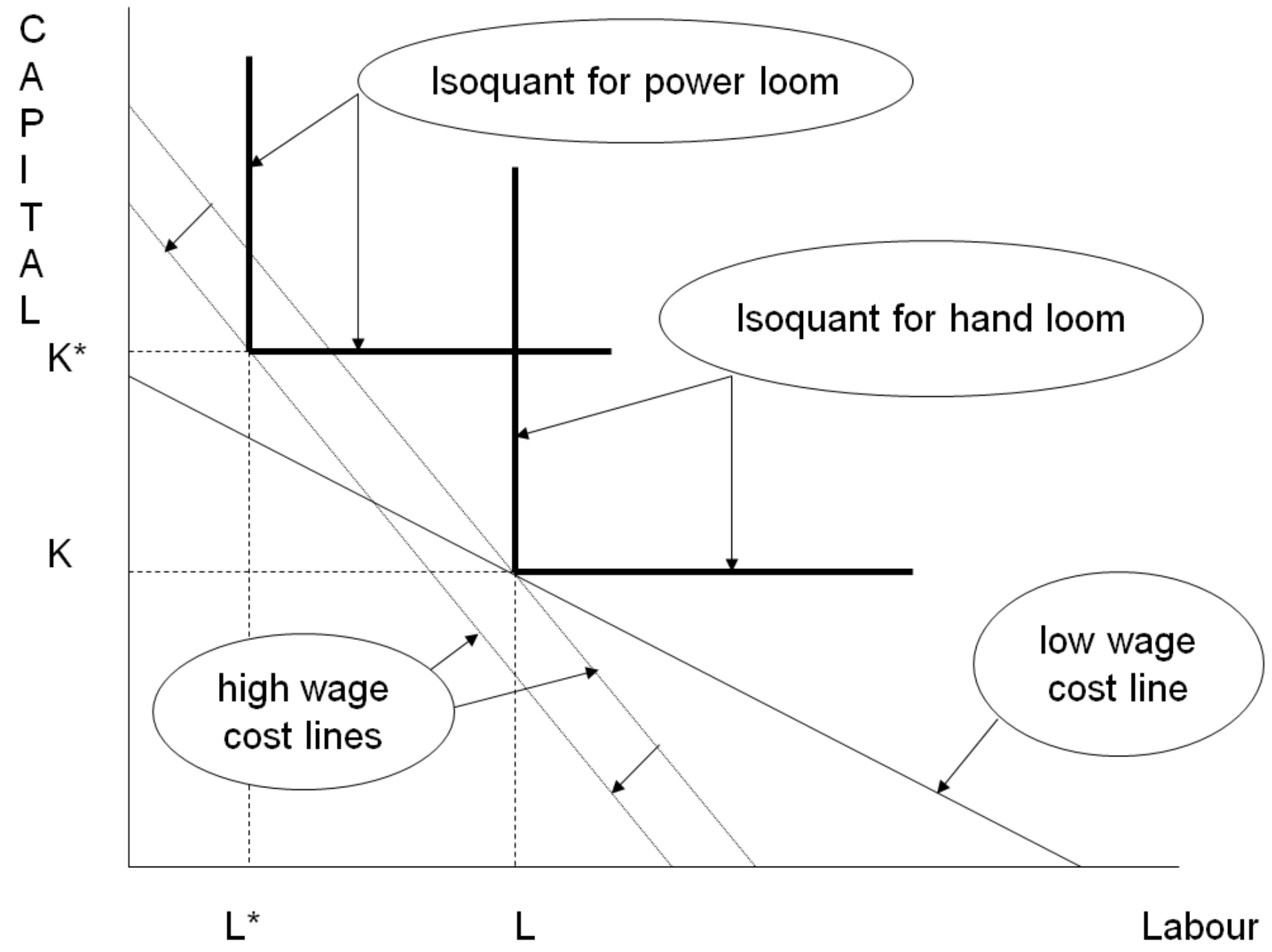


Figure 5

The Trajectory of Improvements and the Tipping Point

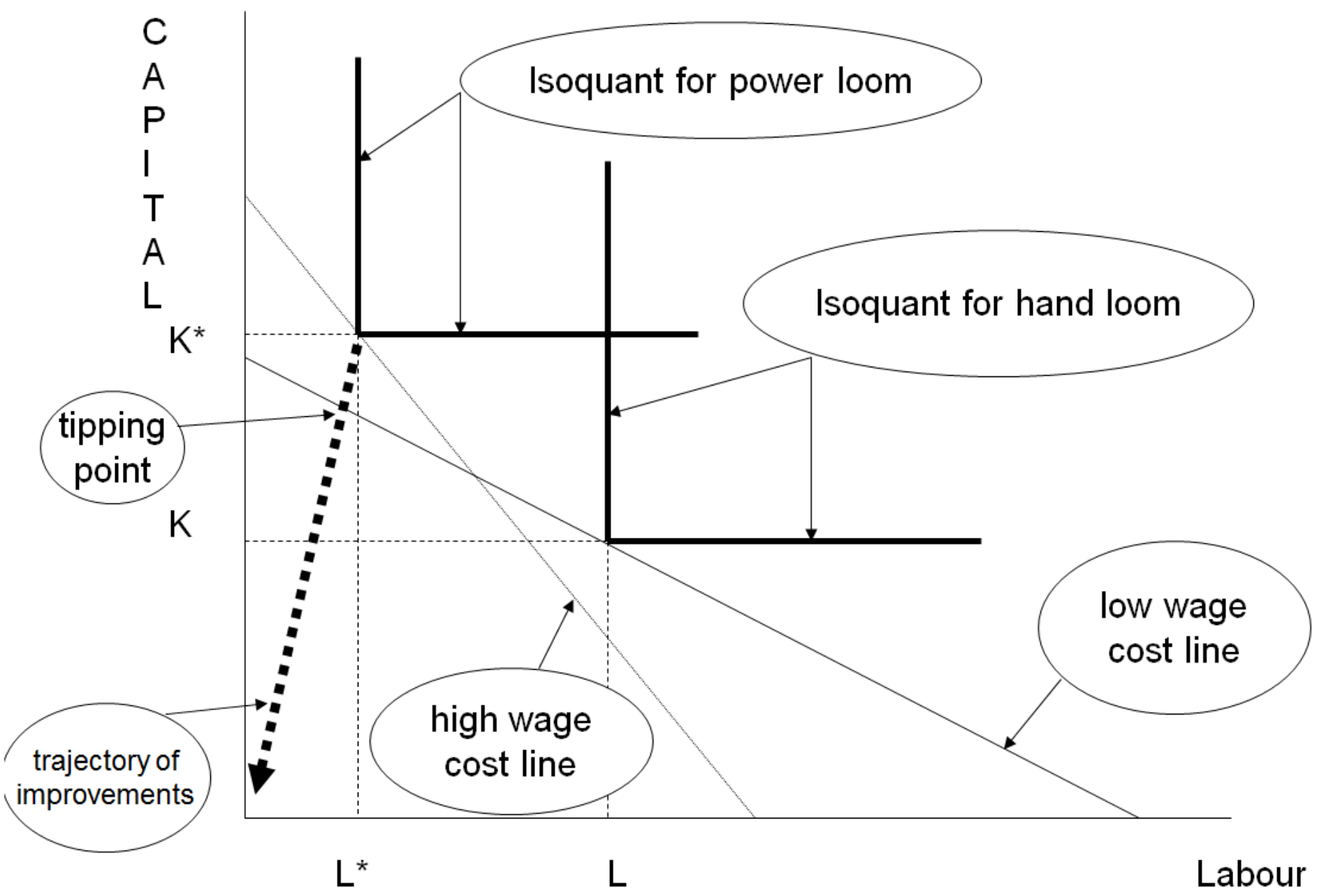


Figure 6

Trajectory of improvements during $R \& D$

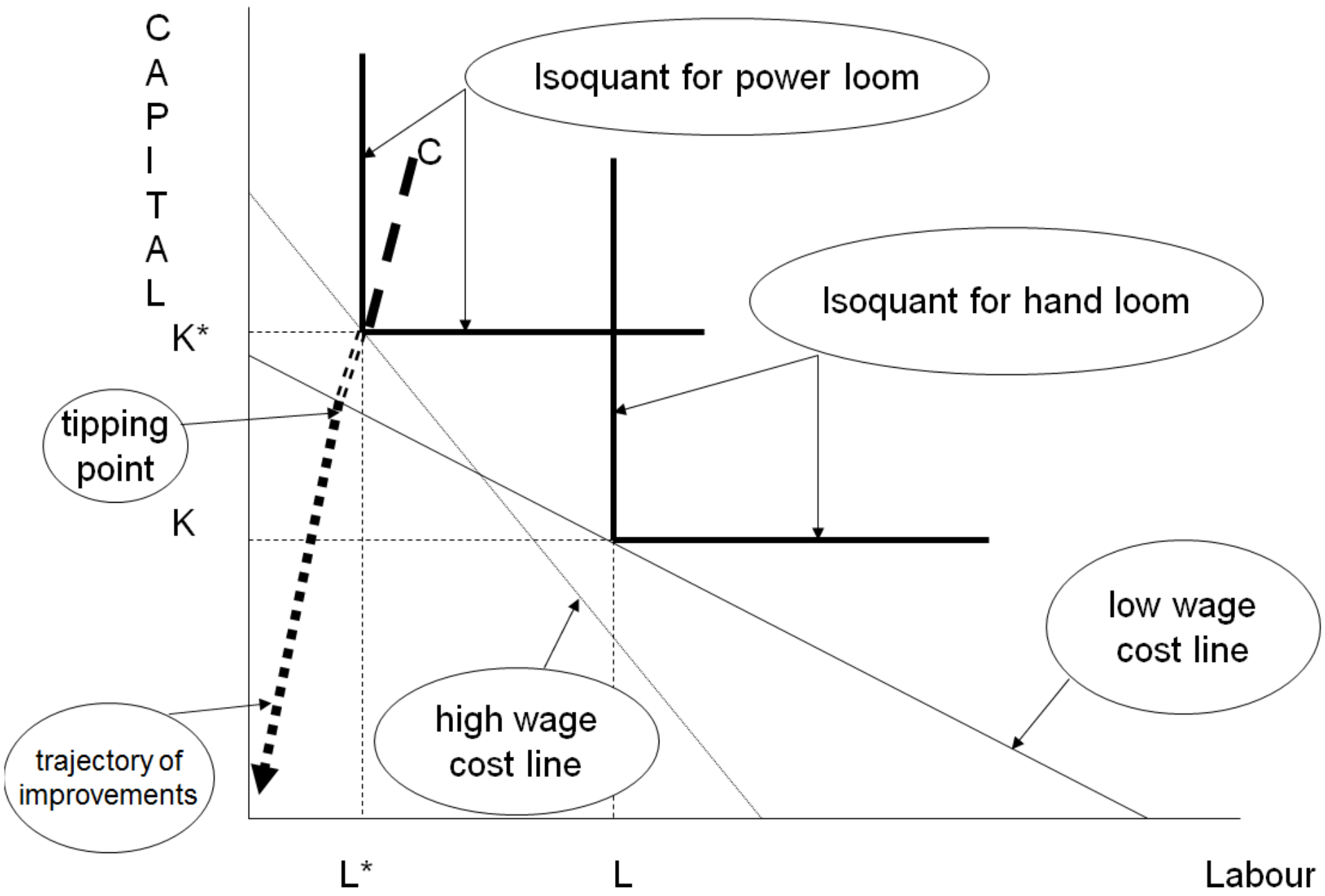


Figure 7

Power loom profitability under various technological specifications

minimum
profit rate
to induce
investment

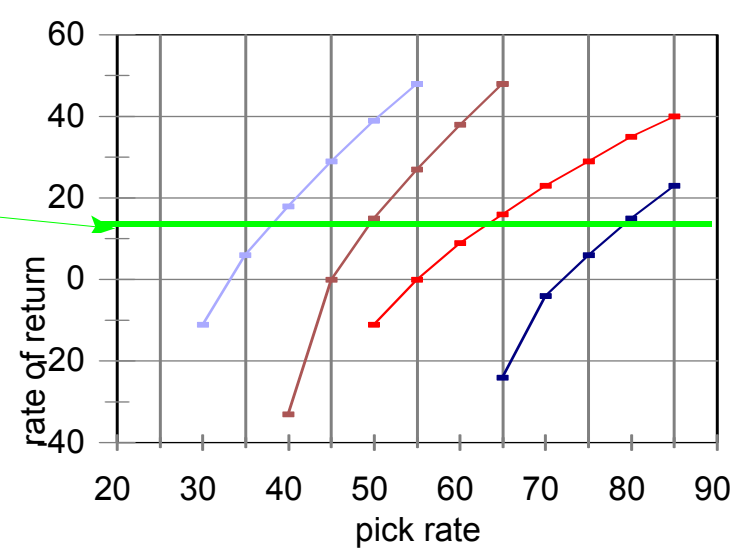

with rents \& dressing machine with rents without dressing machine no rents with dressing machine no rents without dressing machine 
Figure 8

Wage Inequality in Lancashire

( $1=$ bare bones subsistence)

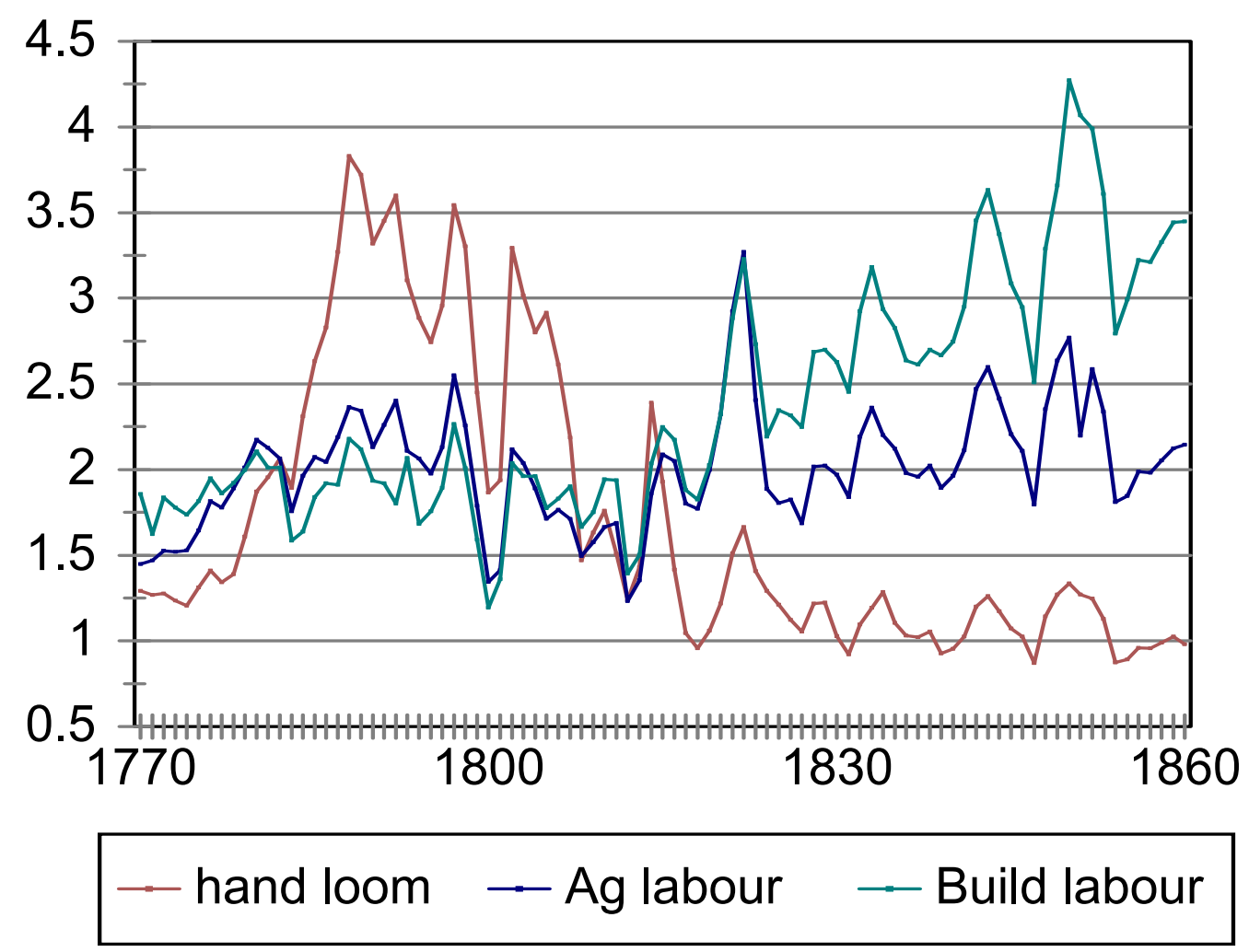

sources:

hand loom weaver-see Figure 1

agricultural labourer-Bowley, (1898, p. 720). Wages implied by Bowley's index numbers. building labourer-see Figure 1.

These nominal wage series were deflated by the subsistence price index described in Allen (2014). 
Appendix: Profitability model for Neild cloth

output

pieces per year $=100$ looms $\times 50$ weeks $/ \mathrm{yr} \times \mathrm{hrs} / \mathrm{wk} /(\mathrm{hrs} /$ piece $)$

hrs/piece $=87696$ picks per piece $/($ effective pick rate per minute $* 60)$

price of output: from Harley (1998, pp. 80-2) and equation 1 as explained in text.

$\underline{\text { costs }}$

yarn

yarn cost per year $(\mathfrak{E})=$ output $*$ yarn cost per piece $/ 240$

yarn cost per piece $(d)=189.2669$

$=2.215 \mathrm{lb} /$ piece $*$ price warp $+2.415 \mathrm{lb} /$ piece $*$ price of weft

The calculations require the prices of 36 count warp and weft yarn. Lyons (1977, p. 199) presents estimated time series from 1818 onwards. Earlier years were deduced from Harley (1998, p. 75), who presents prices of 28 weft and 30 warp yarns for many years. Prices of 36 warp and weft were estimated for these years by applying Lyon's (1977, p. 75) ratios of the prices of warp and weft 36 to the prices of weft 28 and warp 30. Other missing years estimated from corresponding ratios to the prices Harley $(1998$, p. 75$)$ reports for weft 18 and warp 40 over the period 1784 to 1827.

$\underline{\text { coal }}$

coal cost per year $(\mathfrak{£})=$ coal cost per piece $(d) *$ pieces per year $/ 240$

coal cost per piece $(\mathrm{d})=3.32$

$=$ price of coal per $\mathrm{lb}(\mathrm{d}) *$ lbs of coal per HP-hr * HP-hr per piece

horse-power hours per piece $=$ hours per piece $/ 12$

See Lyons (1977, p. 185). Coal price from von Tunzelman (1978, p. 96) for Manchester in 1803.

$\underline{\text { flour }}$

flour cost per year $(\mathfrak{f})=$ flour cost per piece $(\mathrm{d}) *$ pieces per year $/ 240$

flour cost per piece $(d)=1.51=$ price of flour per $\mathrm{lb}(\mathrm{d}) * 0.5 \mathrm{lbs}$ per piece

source: Lyons (1977, pp. 195, 200). Flour price is from Greenwich hospital from Beveridge (1965, p. 291). 
production labour

labour cost per year $(\mathfrak{f})=$ labour cost per piece $(\mathrm{d}) *$ pieces per year $/ 240$

labour cost per piece $(d)=$ sum of cost per piece for winding $(3 d)$, warping $(0.5 d)$, looming (0.75 d), overseeing (2.6 d), dressing, and weaving.

labour cost of dressing $=4.65$ if there is a dressing machine and 0 if no dressing machine labour cost of weaving = wage per week (d) / pieces per weaver per week

pieces per weaver per week $=$ pieces per loom per week $*$ looms per weaver

pieces per loom per week $=$ pieces per year/ $(100$ looms $* 50$ weeks/year $)$

looms per weaver $=2$ if there is a dressing machine and 1 if no dressing machine

Except for weaving, labour cost per piece from Lyons (1977, p. 212) for 1818. For weaving, unit labour cost per piece was computed from the weaver's wage rate of 11 shillings per week as 12 pence per shilling * 11 shillings per week/pieces per weaver per week. Production labour expenses were extrapolated back in time with wage series of women employed as tenters and throstle spinners since most production workers in cotton weaving mills were women. See Feinstein (1998, p 190), for throstle spinners and Bowley (1900, p. 199 facing) for women as tenters.

overhead labour

1 book keeper@324 d/wk

1 engineer@324 d/wk

3 mechanics@172 d/wk

1 watchman@195d/wk

1 size maker@174d/wk

1 sweeper@87d/wk

4 warehousemen@114d/wk

The wage rates shown are for 1818 . Wages were projected to earlier years using the wage rate of labourers in Lancashire as an index.

Lyons (1977, p. 211, 213, 231n3).

overhead expenses

87.5 gallons olive oil $=£ 91.25$

100 shuttles $=£ 20$

100 healds \& staves $=£ 20$

100 reeds $=£ 20$

400 pickers $=£ 8.3$

$300 \mathrm{lbs}$ leather straps $=£ 37.5$ 
75 cleaning brushes $=£ 3$

The total of these expenses was multiplied by two to account for 'other costs'. Lyons (1977, pp. 214, 215, 219)

\section{Interest on working capital}

interest per year $(£)=.05 *(.21 *$ annual revenue $+.13 *$ (production labour + overhead expenses))

investment in fixed capital

100 power looms @£16.5=£1650

Installation of power looms $=£ 202$

4 dressing machines @ £50=£200

120 spindles of winding frames @6s=£36

1 warp mill@£16=£16

2 looming frames@£2=£4

additional machinery investment $=9 \%$ of cost of machinery other than looms $=£ 23.04$ steam engine $=£ 750$

shafting $=£ 275$

mill $=£ 1400$

total fixed investment $=£ 4531.04$

Lyons (1977, pp. 188-193, 216-230). Capital goods prices were unchanging from 1800 onwards, which is the period when the investment decisions were taken (Feinstein 1988, pp. 431,4410 . 


\section{References}

Allen, Robert C. (2015). "The High Wage Economy and the Industrial Revolution: A Restatement," Economic History Review, Vol. 68, No. 1, pp. 1-22.

Acemoglu, Daron, and Robinson, James A. (2012) Why Nations Fail: The Origins of Power, Prosperity, and Poverty, New York, Crown Publishers.

Amalsad, D.M. (1951). Cotton Hand Spinning, Calcutta, Orient Longmans Ltd.

Amalsad, D.M. (1961). Yarn and Cloth Calculation, Calcutta, Orient Longmans Ltd, revised edition.

Bowley, A. L. (1898). 'The Statistics of Wages in the United Kingdom During the Last Hundred Years. (Part I.) Agricultural Wages,' Journal of the Royal Statistical Society, Vol. 61, pp. 702-722.

Bowley, A.L. (1902). "The Statistics of Wages in the United Kingdom During the Last Hundred Years: Wages in the Worsted and Woollen Manufactures of the West Riding of Yorkshire," Journal of the Royal Statistical Society, Vol. 65, pp. 102-26.

Bythell, Duncan (1969). The Handloom Weavers: A Study in the English Cotton Industry during the Industrial Revolution, Cambridge, Cambridge University Press.

Charley, William (1862). Flax and its Products in Ireland, London, Bell and Dalby.

Clark, Gregory (2007). A Farewell to Alms: A Brief Economic History of the World, Princeton, Princeton University Press.

Clark, W. A. Graham (1908). Cotton Textile Trade in Turkish Empire, Greece, and Italy, Washington, Government Printing Office.

Cobbett, William (1967). Rural Rides, ed. by Asa Briggs, Everyman's Library, London, J.M. Dent \& Sons, Ltd.

Feinstein, Charles H. (1998). "Wage-Earnings in Great Britain During the Industrial Revolution," in Applied Economics and Public Policy, ed. By Iain Begg and S.G.B. Henry, Cambridge, Cambridge University Press, pp. 181-208.

Hammond, J.L. and Hammond, B (1919). The Town Labourer: 1760-1832, London, $4^{\text {th }}$ impression.

Harley, C.K. (1898). "Cotton Textile Prices and the Industrial Revolution," Economic History Review, Vol. 51, pp.49-83.

Harley, C. Knick (2010). "Prices and Profits in Cotton Textiles during the Industrial Revolution," Oxford University, Working Papers in Economic and Social History, No. 81. 
Hudson, Pat (1986). The Genesis of Industrial Capital: A Study of the West Riding Wool Textile Industry, c. 1750-1850, Cambridge, Cambridge University Press.

Hunt, David (2004). 'Cartwright, Edmund (1743-1823)', Oxford Dictionary of National Biography, Oxford University Press, 2004; online edn, Oct 2007.

[http://www.oxforddnb.com/view/article/4813, accessed 25 Aug 2013]

India (1942). Report of the Fact-Finding Committee (Handloom and Mills), Calcutta, Government of India Press.

Latif, Muhammad Abdul (1997). Handloom Industry of Bangladesh, 1947-90, Dhaka, The University Press ltd.

Mokyr, Joel (2002). The Gifts of Athena: Historical Origins of the Knowledge Economy, Princeton, Princeton University Press.

Marsden, Richard (1895). Cotton Weaving, London, George Bell \& Sons.

Neild, W. (1861). "An account of the prices of printing cloth and upland cotton from 1812 to 1860," Journal of the Statistical Society, Vol. XXIV, pp. 491-7.

North, D.C. and Weingast, B.R. (1989). 'Constitutions and Commitment: Evolution of Institutions Goverining Public Choice in Seventeenth Century England,' Journal of Economic History, Vol. 49, pp. 803-832.

Palgrave, R.H.I. (1926). Palgrave's Dictionary of Political Economy, ed. by H. Higgs, London, Macmillan, second edition.

Schumpeter, Joseph A. (1994). Capitalism, Socialism, and Democracy, London, Routledge, ebook.

Tables of the revenue, population, commerce, \&c. of the United Kingdom and its dependencies. Part I. From 1820 to 1831, both inclusive, British Parliamentary .Papers, 1833, Vol. XLI.

Timmins, Geoffrey (1996). "Technological Change," in Mary B. Rose, ed, The Lancashire Cotton Industry: A History since 1700, Preston, Lancashire Country Books, pp. 29-62.

von Tunzelmann, G.N. (1978). Steam Power and British Industrialization to 1860, Oxford, Clarendon Press.

Voth, Hans-Joachim (2000). Time and Work in England, 1750-1830, Oxford, Clarendon Press.

White, George (1846). A Practical Treatise on Weaving by hand and Power Looms, Glasgow, John Niven.

Wood, G.H. (1910). "The Statistics of Wages in the United Kingdom During the Nineteenth 
Century, Parts XV-XIX, the Cotton Industry," Journal of the Royal Statistical Society, Vol. 73, pp. 39-58, 128-63,283-315, 411-34, 585-626. 

UNIVERSITY OF OXFORD DISCUSSION PAPERS IN ECONOMIC AND SOCIAL HISTORY are edited by

Rui Esteves (Brasenose College, Oxford, OX1 4AJ) Gabriel Geisler Mesevage (Brasenose College, Oxford, OX1 4AJ) 